\title{
PERSEPSI PEMUKA AGAMA TERHADAP BIAS GENDER DITINJAU DARI LATAR BELAKANG SUKU
}

\author{
Dahlia Lubis \\ UIN Sumatera Utara, Indonesia \\ Jl. Willem Iskandar Pasar V Medan Estate, Sumatera Utara, 20371 \\ e-mail: dahlia_iain@yahoo.com
}

\begin{abstract}
The Perception of Islamic Preachers about Gender Bias Reviewed From Ethnic Group Backgrounds. The existence of various studies and literature on gender does not automatically change the society's opinion about gender equality. As such, supporters and opponents of the idea are readily found. One opinion goes as far as saying that gender studies try to alter the teachings of religion itself. In the gender studies has been found that many contributed to the emergence and development of gender biased ideology in Muslim societies, especially in Indonesia. Among those responsible to discriminatory preservation of women are religious leaders who are represented by ustaz and ustazah where they play the role of religious teachings to the Muslim community. This article examines the opinions of ustaz and ustazah on gender inequality realized from the background of each ethnic group, so it will be revealed about whether there is a link between ethnic background of an ustaz and ustazah to their perception of gender injustice. Based on field studies, where the research data was obtained from questionnaires and interviews, this study found that there is an understanding of gender bias in ustaz and ustazah perceptions in Medan city. This study is expected to contribute to gender studies in Indonesia.
\end{abstract}

Keywords: ustaz, ustazah, injustice, gender, ethnic group 


\section{Pendahuluan}

Kajian terhadap persepsi pemuka agama dalam komunitas Muslim tentang ketidakadilan gender penting dilakukan mengingat peran mereka sebagai penyampai ajaran agama di masyarakat. Akan tetapi, persepsi mereka terhadap peran kesetaraan dan keadilan gender akan dipengaruhi oleh berbagai faktor. Persepsi mereka bisa jadi ditentukan oleh faktor kepribadian, lingkungan, sistem nilai, pendidikan, latar belakang budaya, dan suku. Faktorfaktor yang beragam tersebut pada akhirnya bisa membentuk persepsi setiap orang baik laki-laki maupun perempuan. ${ }^{1}$ Latar belakang suku selain jenis kelamin dan pendidikan dimungkinkan akan memengaruhi persepsi mereka perihal ketidakadilan gender. Sebab itu, dipandang menarik mengkaji persepsi mereka tentang ketidakadilan gender ditinjau dari latar belakang suku masingmasing.

Secara teoretis, ketidakadilan gender termanisfestasikan dalam berbagai bentuk: marginalisasi, stereotipe, kekerasan, peran ganda, dan subordinasi. ${ }^{2}$ Untuk memudahkan pelaksanaan penelitian, masalah akan dibatasi dengan melihat bagaimanakah persepsi para pemuka agama di Medan terhadap keadilan gender ditinjau dari latar belakang suku. Ada indikasi bahwa latar belakang suku memiliki kontribusi terhadap persepsi para pemuka agama tentang ketidakadilan gender. Kajian ini dipandang baru mengingat belum ada kajian perihal pandangan ustaz dan ustazah terhadap ketidakadilan gender. ${ }^{3}$

\section{Metode Penelitian}

Secara metodologis, penelitian ini dilakukan terhadap para pemuka agama yang merupakan ustaz dan ustazah yang ada di pinggiran Kota Medan. Jadi, populasi penelitian ini adalah seluruh pemuka agama dalam masyarakat Muslim, yakni para 


\section{JOIRNAL OF CONTENPORARY ISLAN AND MISSLIM SOCIETIES}

ustaz dan ustazah di Medan. Secara kuantitas, ustaz dan ustazah yang ada di seluruh lima kecamatan di Medan berjumlah 135 orang. Sampel ditentukan secara purposive sampling. Sampel ini dilakukan untuk memperoleh responden yang diharapkan dapat mewakili jenis suku. Sampel yang didapatkan sebesar 45 orang ustaz dan ustazah dengan katagori dari suku Jawa (11 orang), Batak (12 orang), Melayu (10 orang), dan kategori lainlain (12 orang). Data dikumpulkan melalui angket, dan wawancara tidak terstruktur kepada beberapa responden penelitian yang diminta mengisi angket penelitian tersebut. Analisis data yang digunakan adalah analisis kuantitatif dengan teknik presentasi dan korelasi. Data yang dikumpulkan dengan wawancara akan dijabarkan secara deskriptif.

\section{Hasil dan Pembahasan \\ Persepsi Ustaz dan Ustazah terhadap Marginalisasi}

Bagian ini membahas bagaimana persepsi para pemuka agama dalam komunitas Muslim di Medan tentang marginalisasi. Mereka yang dimintai responsnya adalah para ustaz dan ustazah yang berasal dari berbagai suku. Akan dilihat bagaimana para pemuka dari berbagai suku menyikapi masalah marginalisasi.

Persoalan yang ditanyakan kepada mereka adalah perihal haruskah seorang istri meminta izin suami ketika keluar rumah, haruskah perempuan menerima gaji lebih kecil dari laki-laki dalam pekerjaan yang sama, haruskah istri minta izin suami bila hendak meminjam uang di bank, haruskah suami diutamakan dari istri dalam segala hal, haruskah perempuan mengalah kepada suami, dan pekerjaan istri dianggap tidak utama karena tidak mengandung nilai ekonomi ketimbang pekerjaan suami. Kajian di bagian ini akan melihat persepsi para ustaz dan ustazah dengan latarbelakang suku yang berbeda. 
Setelah dilakukan pengumpulan data tentang marginalisasi berdasarkan suku, diperoleh data bahwa para ustaz dan ustazah yang bersuku Jawa tidak memiliki kesamaan persepsi perihal seorang istri harus minta izin setiap kali keluar rumah kepada suaminya. Sebanyak 7 orang $(63.63 \%)$ setuju dengan hal itu, sedangkan 4 orang lainnya atau sebanyak $36.37 \%$ menyatakan tidak perlu minta izin. Demikian halnya para ustaz dan ustazah yang bersuku Batak, dimana 6 orang (50\%) menyatakan setuju bahwa setiap kali keluar rumah istri harus minta izin kepada suaminya, sedangkan 6 orang lainnya (50\%) menyatakan tidak setuju. Pada ustaz dan ustazah yang bersuku Melayu seluruhnya 10 orang $(100 \%)$ menyatakan tidak setuju, sebagaimana mereka yang berasal dari suku yang termasuk pada kategori lain-lain yang seluruhnya sebanyak 12 orang (100\%) menyatakan tidak setuju dengan pernyataan ini.

Dapat disimpulkan bahwa persepsi para ustaz dan ustazah terhadap persoalan marginalisasi berdasarkan katagori suku mereka adalah bahwa para ustaz dan ustazah bersuku Jawa lebih banyak berpendapat bahwa setiap keluar rumah harus minta izin keluar rumah kepada suaminya. Mereka beralasan bahwa suami harus mengetahui kegiatan atau ke mana istri pergi agar diketahui keberadaannya. Para ustaz dan ustazah dari suku Batak yang menjadi responden pada penelitian ini berpendapat bahwa istri harus minta izin kepada suami. Dari suku Melayu dan suku kategori lain-lain lebih banyak mengatakan bahwa istri tidak perlu minta izin setiap kali keluar rumah.

Pada persoalan bahwa gaji seorang perempuan layak lebih kecil dari pada gaji seorang laki-laki dimana jenis pekerjaannya adalah sama, terlihat bahwa 11 orang (100\%) ustaz dan ustazah yang bersuku Jawa tidak setuju dengan hal itu. 12 orang (100\%) ustaz dan ustazah bersuku Batak, 10 orang (100\%) ustaz dan 


\section{JOIRNAL OF CONTENPORARY ISLAN AND MISSLIM SOCIETIES}

ustazah yang bersuku Melayu, dan 12 orang (100\%) pada kategori suku lain-lain juga menyatakan tidak setuju dengan pernyataan bahwa gaji perempuan layak lebih kecil dari gaji laki-laki untuk jenis pekerjaan yang sama.

Berkenaan dengan akses ke bank bahwa seorang istri tidak bisa meminjam uang ke bank tanpa izin suaminya, seluruhnya dari suku menyatakan setuju bila dinyatakan istri tidak bisa meminjam uang ke bank tanpa izin suaminya.

Berkenaan dengan suami harus diutamakan dari istri, 4 orang (36.37\%) ustaz dan ustazah yang bersuku Jawa menyatakan setuju apabila suami harus diutamakan dalam segala hal, sedangkan 7 orang $(63.63 \%)$ ustaz dan ustazah menyatakan tidak setuju. Seluruh ustaz dan ustazah yang berasal dari suku Batak, Melayu dan lain-lain menyatakan tidak setuju apabila suami harus diutamakan dalam segala hal. Secara umum, mereka berpendapat bahwa suami dalam segala hal tidak harus diutamakan, hanya sebagian kecil dari ustaz dan ustazah yang bersuku Jawa yang berpendapat bahwa suami harus diutamakan dalam segala hal.

Sebaliknya berkenaan dengan posisi perempuan terhadap laki-laki, 3 orang (27.27\%) ustaz dan ustazah bersuku Jawa menyatakan setuju bila perempuan harus mengalah kepada laki-laki, dan 8 orang $(72.73 \%)$ menyatakan tidak setuju bila perempuan harus mengalah kepada laki-laki dalam segala hal. Para ustaz dan ustazah yang bersuku Batak sebanyak 3 orang (25\%) menyatakan setuju, dan 9 orang $(75 \%)$ menyatakan tidak setuju. Sedangkan ustaz dan ustazah yang bersuku Melayu sebanyak 2 orang (20\%) menyatakan setuju, dan sebanyak 8 orang (20\%) menyatakan tidak setuju. Sedangkan ustaz dan ustazah bersuku kategori lain-lain sebanyak 2 orang (16.66\%) menyatakan setuju, dan sebanyak 10 orang (83.34\%) menyatakan tidak setuju. Sebagian besar ustaz dan ustazah menyatakan bahwa perempuan tidak harus mengalah kepada suami. 
Pandangan terhadap pekerjaan istri dalam rumah tangga, seluruh ustaz dan ustazah yang bersuku Jawa dan Batak tidak setuju bila dikatakan pekerjaan istri dianggap tidak utama karena tidak mengandung nilai ekonomi. Sebanyak 3 orang (30\%) ustaz dan ustazah bersuku Melayu menyatakan setuju bahwa pekerjaan istri tidaklah utama karena tidak memuat nilai ekonomi, dan sebanyak 7 orang (70\%) menyatakan tidak setuju bila dikatakan bahwa pekerjaan istri dalam rumah tangga tidak utama karena tidak mengandung nilai ekonomi. Suku yang termasuk kategori lain-lain seluruhnya 12 orang (100\%) menyatakan tidak setuju dengan pernyataan itu.

\section{Persepsi Ustaz dan Ustazah terhadap Stereotipe}

Bagian ini akan mengkaji bagaimana persepsi para ustaz dan ustazah dari beragam suku terhadap persoalan stereotipe. Akan dilihat persepsi mereka tentang pernyataan bahwa perempuan bersifat cengeng dan pemalu, sedangkan laki-laki bersifat pemberani dan tegas; perempuan lebih lemah dari laki-laki secara fisik; pekerjaan rumah tangga adalah tanggung jawab istri; dan mengasuh anak adalah tugas istri.

Dari data yang dikumpulkan dapat disimpulkan bahwa seluruh ustaz dan ustazah dari semua suku baik Jawa, Batak, Melayu maupun suku yang kategori lain-lain menyatakan tidak setuju apabila dikatakan semua perempuan bersifat cengeng dan pemalu. Mereka beralasan bahwa fakta di lapangan menunjukkan banyak perempuan yang bersifat tegas.

Perihal pendapat mereka terhadap pernyataan bahwa semua laki-laki memiliki sifat pemberani dan bersifat tegas, ditemukan bahwa 7 orang (63.63\%) ustaz dan ustazah bersuku Jawa menyatakan setuju, dan sebanyak 4 orang $(36.37 \%)$ menyatakan tidak setuju. Sebanyak 4 orang (33.33\%) ustaz dan ustazah bersuku Batak 


\section{JOIRNAL OF CONTENPORARY ISLAN AND MISSLIM SOCIETIES}

menyatakan setuju bahwa laki-laki semuanya bersifat tegas dan pemberani dan sebanyak 8 orang $(66.67 \%)$ menyatakan tidak setuju. Seluruh ustaz dan ustazah bersuku Melayu dan suku yang termasuk kategori lain-lain menyatakan tidak setuju bila dikatakan semua laki-laki bersifat pemberani dan tegas.

Berkaitan dengan pernyataan bahwa semua perempuan secara fisik lebih lemah dari laki-laki, ditemukan bahwa sebanyak 6 orang (54.55\%) ustaz dan ustazah bersuku Jawa menyatakan setuju, dan sebanyak 5 orang (45.45\%) menyatakan tidak setuju. Sebanyak 9 orang $(75 \%)$ ustaz dan ustazah bersuku Batak menyatakan setuju terhadap pernyataan bahwa perempuan secara ûsik lebih lemah dari laki-laki, dan sebanyak 3 orang (25\%) menyatakan tidak setuju. Sedangkan seluruh ustaz dan ustazah bersuku Melayu 10 orang $(100 \%)$ menyatakan tidak setuju apabila dikatakan semua perempuan secara fisik lebih lemah dari laki-laki.

Seluruh ustaz dan ustazah dari semua suku, kecuali suku yang masuk kategori lain-lain, menyatakan tidak setuju apabila dikatakan bahwa pekerjaan rumah tangga hanya tanggungjawab istri saja. Sebanyak 4 orang (33.33\%) dari suku kategori lainlain menyatakan setuju apabila pekerjaan rumah tangga adalah tanggung jawab istri saja, dan sebanyak 8 orang (66.67\%) menyatakan tidak setuju. Jadi, hampir seluruh ustaz dan ustazah dari semua suku berpendapat bahwa pekerjaan rumah tangga bukan tugas istri saja.

Ditemukan pula bahwa sebanyak 4 (empat) orang (36.37\%) ustaz dan ustazah yang bersuku Jawa menyatakan setuju apabila dikatakan bahwa pekerjaan mengasuh dan mendidik anak adalah pekerjaan istri saja. Sebanyak 7 orang (63.63\%) menyatakan tidak setuju tentang hal ini. Persepsi ustaz dan ustazah dari suku Batak menunjukkan bahwa sebanyak 5 orang (41.66\%) menyatakan setuju, dan sebanyak 7 orang (58.34) menyatakan tidak setuju. Adapun persepsi ustaz dan ustazah yang bersuku 
Melayu menunjukkan bahwa sebanyak 3 orang (30\%) menyatakan setuju. Sebanyak 7 orang (70\%) menyatakan tidak setuju tentang hal ini. Sedangkan ustaz dan ustazah yang bersuku kategori lain-lain, sebanyak 4 orang $(33.33 \%)$ menyatakan setuju, dan selebihnya sebanyak 8 orang (66.67\%) menyatakan tidak setuju tentang pernyataan bahwa mengasuh anak dan mendidik anak adalah tugas dan tanggung jawab istri saja.

\section{Persepsi Ustaz dan Ustazah terhadap Kekerasan}

Bagian ini akan mengkaji persepsi ustaz dan ustazah terhadap persoalan kekerasan terhadap perempuan. Secara khusus, akan dilihat persepsi mereka tentang persoalan nafkah suami terhadap istri, pelayanan seksual kepada suami, hak cerai istri, dan kepatuhan istri terhadap suami.

Setelah dilakukan pengumpulan data, dapat dilihat bahwa seluruh ustaz dan ustazah dari semua suku menyatakan tidak setuju apabila dikatakan bahwa istri boleh dipukul oleh suami bila istri bersalah. Secara umum, mereka beralasan istri dinasehati saja atau istri bukan untuk disakiti.

Sebanyak 6 orang (54.54\%) ustaz dan ustazah yang bersuku Jawa setuju terhadap pernyataan bahwa apabila suami tidak memberi nafkah istrinya, maka suami masih menjadi pemimpin rumah tangga, dan sebanyak 5 orang (45.45\%) tidak setuju dengan pernyataan ini. Sebanyak 5 orang (41.67\%) ustaz dan ustazah bersuku Batak setuju apabila suami yang tidak memberi nafkah kepada keluarganya, maka suami masih menjadi pemimpin rumah tangga, dan sebanyak 7 orang (58.33\%) menyatakan tidak setuju. Sedangkan sebanyak 3 orang (30\%) ustaz dan ustazah bersuku Melayu menyatakan setuju dengan pernyataan itu, dan 7 orang (70\%) menyatakan tidak setuju. Pada suku kategori lain-lain, 6 orang (50\%) ustaz dan ustazah menyatakan setuju, 


\section{JOIRNAL OF CONTENPORARY ISLAN AND MISSLIM SOCIETIES}

dan sebanyak 6 orang (50\%) menyatakan tidak setuju. Jadi, ustaz dan ustazah dari suku Jawa lebih banyak mengatakan bahwa suami masih tetap dan layak menjadi pemimpin rumah tangga, sekalipun tidak memenuhi kewajibannya memberi nafkah istrinya. Sebaliknya, suku Batak dan Melayu lebih banyak menyatakan bahwa suami tidak lagi menjadi pemimpin rumah tangga karena suami tidak lagi memberi nafkah istrinya.

Dalam masalah seksual, persepsi ustaz dan ustazah terhadap pernyataan bahwa suami harus dilayani kapan pun dia mau adalah sebagai berikut. Sebanyak 1 orang (9.09\%) ustaz dan ustazah bersuku Jawa menyatakan setuju, dan sebanyak 10 orang (90.91\%) menyatakan tidak setuju. Sementara seluruh ustaz dan ustazah bersuku Batak dan Melayu menyatakan tidak setuju terhadap pernyataan suami harus dilayani kapapun dia mau. Sebanyak 1 orang dari suku kategori lain-lain (8.33\%) menyatakan setuju, dan sebanyak 1 orang (91.67\%) menyatakan tidak setuju terhadap pernyataan ini. Jadi, sebagian kecil saja yang berpendapat bahwa suami harus dilayani kapan pun dia mau.

Terkait persoalan hak cerai, persepsi ustaz dan ustazah dari suku Jawa adalah bahwa sebanyak 5 orang $(45.45 \%)$ dari mereka menyatakan bahwa istri memiliki hak cerai, dan 6 orang $(54.55 \%)$ menyatakan tidak setuju. Sebanyak 8 orang $(66.67 \%)$ bersuku Batak menyatakan setuju terhadap pernyataan ini, dan sebanyak 4 orang (33.33\%) menyatakan tidak setuju. Sebanyak 6 orang (54.55\%) ustaz dan ustazah bersuku Melayu menyatakan setuju, dan sebanyak 4 orang (40\%) menyatakan tidak setuju terhadap pernyataan istri memiliki hak cerai dari suaminya. Sementara sebanyak 7 orang $(54.55 \%)$ ustaz dan ustazah dari suku kategori lain-lain menyatakan setuju, dan sebanyak 5 orang $(45.45 \%)$ menyatakan bahwa istri tidak memiliki hak cerai dari suaminya. Tampak lebih dari separuh yang dari ustaz dan ustazah masing- 
masing suku mengatakan bahwa istri memiliki hak cerai dari suaminya.

Berkaitan dengan pernyataan bahwa seorang istri wajib mematuhi semua kata-kata dan perintah suami, ditemukan bahwa sebanyak 10 orang $(90.91 \%)$ ustaz dan ustazah bersuku Jawa setuju dengan pernyataan itu, dan sebanyak 1 orang (9.09\%) menyatakan tidak setuju. Seluruh ustaz dan ustazah bersuku Batak tidak setuju. Sebanyak 3 orang $(30 \%)$ ustaz dan ustazah bersuku Melayu menyatakan setuju, dan sebanyak 7 orang (70\%) menyatakan tidak setuju. Sebanyak 8 orang $(60.67 \%)$ dari suku lain-lain menyatakan setuju, dan sebanyak 4 orang (33.44\%) menyatakan tidak setuju bila perempuan (istri) harus mematuhi semua semua kata-kata suaminya. Jadi, hampir seluruh suku jawa berpendapat bahwa istri wajib mematuhi semua kata-kata suami.

\section{Persepsi Ustaz dan Ustazah terhadap Peran Ganda}

Bagian ini akan mengkaji persepsi ustaz dan ustazah terhadap persoalan peran ganda. Secara khusus akan dikaji tentang persoalan istri yang bekerja di luar, suami membantu pekerjaan rumah, tugas lelaki sebagai pencari nafkah, dan perempuan bekerja di luar rumah.

Pengumpulan data terhadap indikator ini menunjukkan bahwa sebanyak 4 orang (36.37\%) ustaz dan ustazah bersuku jawa setuju bahwa sekalipun istri yang bekerja di luar, pekerjaan rumah tangga sepenuhnya menjadi tugas dan tanggung jawab istri, dan sebanyak 7 orang (63.63\%) tidak setuju dengan pertanyaan ini. Ditemukan pula bahwa sebanyak 4 orang $(33.33 \%)$ ustaz dan ustazah bersuku Batak menyatakan tidak setuju dengan hal itu, dan sebanyak 8 orang (66.67\%) menyatakan tidak setuju apabila dikatakan bahwa sekalipun istri bekerja di luar, pekerjaan rumah tangga tetap menjadi tugas dan tanggung jawab istri. 


\section{JOIRNAL OF CONTEVPORARY ISLAN AND MISSLIM SOCIETIES}

Ditemukan juga bahwa sebanyak 4 orang ustaz dan ustazah bersuku Melayu (40\%) menyatakan setuju, dan sebanyak 6 orang $(60 \%)$ menyatakan tidak setuju. Sedangkan ustaz dan ustazah dari suku kategori lain-lain sebanyak 5 orang $(41.67 \%)$ menyatakan setuju, dan sebanyak 7 orang (59.33\%) menyatakan tidak setuju dengan pernyataaan bahwa istri yang bekerja di luar, pekerjaan rumah tangga sepenuhnya masih tugas dan tanggungjawab istri. Secara umum, ustaz dan ustazah berdasarkan suku lebih banyak yang berpendapat bahwa apabila istri bekerja di luar rumah, maka pekerjaan rumah tangga menjadi tidak hanya menjadi tanggung jawab istri saja, tetapi menjadi tanggung jawab bersama.

Terkait pernyataan bahwa suami membantu pekerjaan istri di rumah adalah hal yang memalukan, sebanyak 2 orang (18.18\%) ustaz dan ustazah bersuku Jawa menyatakan setuju terhadap pernyataan ini, dan sebanyak 9 orang $(81.82 \%)$ menyatakan tidak setuju. Dari ustaz dan ustazah bersuku Batak, 2 orang (16.67\%) menyatakan setuju, dan 10 orang (83.33\%) menyatakan tidak setuju. Mayoritas mengatakan bahwa bukanlah hal yang memalukan bila suami membantu pekerjaan istri.

Terhadap pernyataan bahwa laki-laki tugasnya hanya mencari nafkah saja, ditemukan bahwa seluruh ustaz dan ustazah bersuku Jawa berpendapat tidak setuju. Sebanyak 5 orang (41.67\%) ustaz dan ustazah bersuku Batak menyatakan setuju, dan 7 orang $(58.33 \%)$ menyatakan tidak setuju bila laki-laki tugasnya hanya mencari nafkah di luar rumah. Seluruh ustaz dan ustazah bersuku Melayu seluruhnya menyatakan tidak setuju terhadap pandangan ini. Dari seluruh ustaz dan ustazah bersuku kategori lain-lain, ditemukan sebanyak 4 orang $(33.33 \%)$ menyatakan setuju, dan 8 orang $(66.67 \%)$ menyatakan tidak setuju bila laki-laki tugasnya hanya mencari nafkah di luar rumah. Jadi, hampir semua suku menyatakan laki-laki tugasnya tidak hanya mencari nafkah di luar rumah saja tetapi juga mengurus rumah tangga. 
Mengenai tugas istri mengasuh anak dan mengurus rumah tangga tidak bisa digantikan oleh suami, ditemukan bahwa sebanyak 3 orang (27.27\%) ustaz dan ustazah bersuku Jawa menyatakan setuju, dan 8 orang (72.73\%) menyatakan tidak setuju. Sebanyak 3 orang $(75 \%)$ ustaz dan ustazah bersuku Batak menyatakan setuju, dan 9 orang $(75 \%)$ menyatakan tidak setuju. Sebanyak 1 $(10 \%)$ orang ustaz dan ustazah bersuku Melayu menyatakan setuju, dan 9 orang (90\%) menyatakan tidak setuju. Ustaz dan ustazah bersuku kategori lain-lain 2 orang $(16.67 \%)$ menyatakan setuju, dan 10 orang (83.33\%) menyatakan tidak setuju bila tugas mengasuh anak dan mengurus rumah tangga tidak bisa digantikan. Hal ini berarti bahwa sebagian besar ustaz dan ustazah berdasarkan suku mengurus rumah tangga dan mengasuh anak bisa digantikan laki-laki.

Ditemukan bahwa sebanyak 9 orang $(81.82 \%)$ ustaz dan ustazah bersuku Jawa menyatakan setuju bahwa perempuan boleh bekerja asal tidak meninggalkan pekerjaan mengurus rumah tangga, dan sebanyak 2 orang $(18.18 \%)$ menyatakan tidak setuju. Sebanyak 7 orang (58.33\%) ustaz dan ustazah bersuku Batak menyatakan tidak setuju dengan pernyataan ini, dan sebanyak 5 orang (41.46\%) menyatakan tidak setuju. Sebanyak 9 orang $(90 \%)$ ustaz dan ustazah bersuku Melayu menyatakan setuju bila perempuan bekerja di luar rumah asal tidak meninggalkan pekerjaan rumah tangga, dan hanya sebanyak 1 orang (10\%) yang menyatakan tidak setuju. Sebanyak 8 orang (66.67\%) dari ustaz dan ustazah bersuku kategori lain-lain menyatakan setuju, dan 4 orang (33.33\%) menyatakan tidak setuju dengan pernyataan ini. Jadi, sebagian besar ustaz dan ustazah dari semua suku yang menjadi responden boleh bekerja di luar asal tidak meninggalkan tanggung jawab megurus rumah tangga.

Berkaitan dengan pernyataan pekerjaan rumah tangga hanya pantas dilakukan oleh perempuan saja, ditemukan bahwa sebanyak 


\section{JOIRNAL OF CONTENPORARY ISLAN AND MISSLIM SOCIETIES}

1 orang (9.09\%) ustaz dan ustazah bersuku Jawa menyatakan setuju dan sebanyak 10 orang (80.91) menyatakan setuju. Sebanyak 3 orang $(25 \%)$ ustaz dan ustazah bersuku Batak menyatakan setuju, dan 9 orang (75\%) menyatakan tidak setuju. Hanya 2 orang $(20 \%)$ ustaz dan ustazah bersuku Melayu yang menyatakan setuju, dan 8 orang (80\%) menyatakan tidak setuju. Sementara itu sebanyak 2 orang $(16.67 \%)$ ustaz dan ustazah yang bersuku kategori lain-lain yang menyatakan setuju dan selebihnya 8 orang $(83.33 \%)$ yang menyatakan tidak setuju. Sebagian besar mereka berpendapat bahwa pekerjaan istri pantas dilakukan laki-laki.

\section{Persepsi Ustaz dan Ustazah terhadap Subordinasi}

Bagian ini akan mengkaji persepsi ustaz dan ustazah terhadap subordinasi. Secara khusus akan dikaji persepsi mereka tentang peran perempuan dalam pengambilan keputusan, pendidikan lelaki harus lebih tinggi dari perempuan, pimpinan harus lakilaki, lelaki lebih cerdas dari perempuan, dan persoalan kepemimpinan perempuan.

Berdasarkan data, ditemukan bahwa sebanyak 10 orang (90.91\%) ustaz dan ustazah bersuku Jawa menyatakan setuju, dan hanya 1 orang (9.09\%) menyatakan tidak setuju. Sebanyak 10 orang (83.33\%) ustaz dan ustazah bersuku Batak menyatakan setuju bahwa istri harus dilibatkan dalam pengambilan keputusan dalam rumah tangga, dan hanya 2 orang (16.6.7\%) yang menyatakan tidak setuju. Sebanyak 7 orang (70\%) bersuku Melayu menyatakan setuju dan 3 orang (30\%) menyatakan tidak setuju istri dilibatkan dalam pengambilan keputusan dalam keluarga. Sebanyak 9 orang (75\%) ustaz dan ustazah dari suku kategori lain-lain menyatakan setuju istri dilibatkan dalam pengambilan keputusan dalam rumah tangga, dan 3 orang (25\%) yang menyatakan tidak setuju. 
Secara umum bahwa pandangan ustaz dan ustazah berdasarkan suku cenderung menyatakan bahwa dalam pengambilan keputusan seorang suami harus melibatkan istri.

Mengenai pendidikan laki-laki seharusnya lebih tinggi dari perempuan, ditemukan bahwa sebanyak 4 orang (36.3 7\%) ustaz dan ustazah bersuku Jawa menyatakan setuju, dan 7 orang $(63.63 \%)$ menyatakan tidak setuju. Sebanyak 4 orang $(33.33 \%)$ bersuku Batak menyatakan setuju, dan 8 orang $(66.87 \%)$ menyatakan tidak setuju. Sebanyak 3 orang (30\%) ustaz dan ustazah bersuku Melayu menyatakan setuju, dan 7 orang (70\%) menyatakan tidak setuju. Sebanyak 6 orang (50\%) ustaz dan ustazah bersuku kategori lain-lain menyatakan setuju, dan 6 orang $(50 \%)$ menyatakan tidak setuju bahwa pendidikan laki-laki seharusnya lebih tinggi dari perempuan.

Terhadap pandangan bahwa pemimpin organisasi harus seorang laki-laki, ditemukan bahwa sebanyak 7 orang (63.63\%) ustaz dan ustazah bersuku Jawa menyatakan setuju, dan 4 orang $(36.37 \%)$ menyatakan tidak setuju. Sedangkan 2 orang (16.37\%) ustaz dan ustazah bersuku Batak menyatakan setuju, dan sebanyak 10 orang (83.33\%) menyatakan tidak setuju. Seluruh ustaz dan ustazah bersuku Melayu menyatakan tidak setuju. Dari ustaz dan ustazah bersuku kategori lain-lain, hanya 1 orang $(8.33 \%)$ menyatakan setuju, dan 11 orang (91.67\%) menyatakan tidak setuju dengan pernyataan seorang pemimpin organisasi harus seorang laki-laki. Tampak bahwa suku Jawa yang paling dominan menyatakan bahwa pimpinan organisasi harus laki-laki.

Ditemukan bahwa sebanyak 4 orang (36.37\%) ustaz dan ustazah bersuku Jawa menyatakan setuju bila dikatakan bahwa laki-laki selalu lebih cerdas dari perempuan, dan 7 orang (63.63\%) menyatakan tidak setuju. Seluruh ustaz dan ustazah dari suku Batak, Melayu dan suku kategori lain-lain menyatakan tidak 


\section{JOIRNAL OF CONTENPORARY ISLAN AND MISSLIM SOCIETIES}

setuju bila dikatakan laki-laki selalu lebih cerdas dari perempuan. Jadi, secara umum menyatakan bahwa laki-laki belum tentu lebih cerdas dari perempuan dan hanya sebagian kecil ustaz dan ustazah dari suku Jawa yang menyatakan bahwa laki-laki lebih cerdas dari perempuan. Kesadaran ini didasarkan pada alasan yang dikemukakan oleh mereka bahwa kecerdasan tidak ditentukan oleh jenis kelamin.

Ditemukan pula bahwa sebanyak 9 orang (81.82\%) ustaz dan ustazah bersuku Jawa menyatakan setuju terhadap pernyataan perihal tidak suka kalau perempuan menduduki jabatan lebih tinggi dari laki-laki, dan 2 orang (18.18\%) menyatakan tidak setuju dengan pernyataan ini. Sebanyak 10 orang (83.33\%) ustaz dan ustazah bersuku Batak menyatakan setuju, dan sebanyak 2 orang (16.37\%) tidak setuju. Adapun dari ustaz dan ustazah bersuku Melayu, sebanyak 5 orang (50\%) menjawab setuju, dan 5 orang $(50 \%)$ menjawab tidak setuju. Demikian juga ustaz dan ustazah dari kategori lain-lain, sebanyak 6 orang menjawab setuju, dan 6 orang (50\%) menjawab tidak setuju, dan menganggap tidak mengapa terhadap pernyataan bila perempuan menduduki jabatan lebih tinggi dari laki-laki.

\section{Penutup}

Berdasarkan kajian di atas, dapat disimpulkan bahwa tidak ada kesamaan persepsi para pemuka agama (ustaz dan ustazah) di kota Medan perihal bias gender yang termanifestasikan dalam bentuk marginalisasi, stereotipe, kekerasan, peran ganda, dan subordinasi. Ada banyak temuan menarik dalam penelitian ini, dimana secara umum dapat disampaikan bahwa masih ada pemahaman yang bias gender dalam persepsi pemuka agama yang diteliti, meskipun dalam sebagian persoalan mereka telah menunjukkan gagasan yang adil secara gender. Contoh persepsi 
yang bias gender adalah adanya persepsi para ustaz dan ustazah yang bersuku Jawa dimana mereka lebih banyak yang berpendapat bahwa setiap keluar rumah harus minta izin keluar rumah kepada suaminya. Selain itu, ustaz dan ustazah dari suku Jawa lebih banyak yang mengatakan bahwa suami masih tetap dan layak menjadi pemimpin rumah tangga meskipun tidak lagi memenuhi kewajibannya memberi nafkah istrinya. Mayoritas ustaz dan ustazah dari suku Jawa dan Batak menyatakan bahwa perempuan lebih lemah dari laki-laki. Mayoritas mereka dari suku Jawa dan Melayu menyatakan setuju bahwa istri wajib mematuhi semua perkataan dan perintah suami.

Tetapi, persepsi lain dari mereka menunjukkan bahwa mereka memiliki pemahaman yang adil secara gender. Sekadar contoh, ustaz dan ustazh dari suku Batak dan Melayu lebih banyak menyatakan bahwa suami tidak lagi menjadi pemimpin rumah tangga karena suami tidak lagi memberi nafkah istrinya. Sebagian besar ustaz dan ustazah berpendapat bahwa pekerjaan istri pantas dilakukan laki-laki. Semua dari mereka sepakat bahwa dalam pengambilan keputusan, seorang suami harus melibatkan istri. Mayoritas mereka juga menyatakan bahwa laki-laki belum tentu lebih cerdas dari perempuan.

Dapat ditegaskan bahwa masih ada kecenderungan bias gender dalam pemikiran para ustaz dan ustazah yang diteliti. Tentu saja hal ini dapat berakibat terhadap masih akan menjamurnya paham bias gender dalam komunitas umat Islam di Medan, Sumatera Utara mengingat peran ustaz dan ustazah sebagai penyebar paham agama ke masyarakat Muslim. Sebab itulah, perlu ada semacam kegiatan penataran bagi para ustaz dan ustazah yang ada di kota Medan untuk menyampaikan informasi perihal urgensi dari penegakan keadilan gender, dan penolakan sikap bias gender dalam komunitas masyarakat Muslim. 
JOIRNAL OF CONTEVPORARY ISLAM AND MISLIM SOCIETIES

\section{Pustaka Acuan}

Basyir, Kunawi. "Menggugat Syirik Intelektual Bersama Nasr Hâmid Abû Zayd dan Amina Wadud," dalam Teosofi: Jurnal Tasawuf dan Pemikiran Islam, Vol. 1, No. 2, 2011.

Damanuri, Aji. "Muslim Diaspora dalam Isu Identitas, Gender, dan Terorisme," dalam Islamica: Jurnal Studi Keislaman, Vol. 6 No. 2, 2012.

Fakih, Mansour. Analisis Gender dan Transformasi Sosial. Yogyakarta: Pustaka Pelajar, 1999.

Fauziyah, Yayuk. "Ulama Perempuan dan Dekonstruksi Fiqih Patriarkis," dalam Islamica: Jurnal Studi Keislaman, Vol. 5, No. 1, 2010.

Ghofur, Abdul dan Sulistiyono Susilo. "Perempuan dan Narasi Kekerasan: Studi Kritis Peran Gender dalam Deradikalisasi," dalam Teosofi: Jurnal Tasawuf dan Pemikiran Islam, Vol. 5 No. 2, 2015.

Lubis, Dahlia. "Persepsi Mubaligh dan Mubalighah terhadap Kesetaraan dan Keadilan Gender di Kota Medan," dalam MIQOT: Jurnal Ilmu-ilmu Keislaman, Vol. 40, No. 1, 2016.

Nasir, Muhammad. "Syariat Islam dan Ngangkang Style: Mengenal Kearifan Lokal dan Identitas Perempuan Aceh," dalam MIQOT: Jurnal Ilmu-ilmu Keislaman, Vol. 37, No. 1, 2013.

Nasir, Muhammad. "The Resistance of Ulama Dayah Aceh Tamiang Against Women's Rights in Compilation of Islamic Law (KHI)," dalam MIQOT: Jurnal Ilmu-ilmu Keislaman, Vol. 41, No. 1, 2017.

Rofhani. "Ekspresi dan Representasi Budaya Perempuan Muslim Kelas Menengah di Surabaya," dalam Islamica: Jurnal Studi Keislaman, Vol. 11 No. 2 (2017).

Rozalinda dan Nurhasanah. "Persepsi Perempuan tentang Perceraian di Kota Padang," dalam MIQOT:Jurnal Ilmu-ilmu Keislaman, Vol. 38, No. 2, 2014. 


\section{Catatan Akhir:}

${ }^{1}$ Lihat kajian ini dalam Rozalinda dan Nurhasanah, "Persepsi Perempuan tentang Perceraian di Kota Padang," dalam MIQOT: Jurnal Ilmu-ilmu Keislaman, Vol. 38, No. 2, 2014; Dahlia Lubis, "Persepsi Mubaligh dan Mubalighah terhadap Kesetaraan dan Keadilan Gender di Kota Medan," dalam MIQOT: Jurnal Ilmu-ilmu Keislaman, Vol. 40, No. 1, 2016; Muhammad Nasir, "Syariat Islam dan Ngangkang Style: Mengenal Kearifan Lokal dan Identitas Perempuan Aceh," dalam MIQOT: Jurnal IImu-ilmu Keislaman, Vol. 37, No. 1, 2013.

${ }^{2}$ Lihat pembahasannya dalam Mansour Fakih, Analisis Gender dan Transformasi Sosial (Yogyakarta: Pustaka Pelajar, 1999).

${ }^{3}$ Lihat kajian-kajian mengenai perempuan dan gender dalam Abdul Ghofur dan Sulistiyono Susilo, "Perempuan dan Narasi Kekerasan: Studi Kritis Peran Gender dalam Deradikalisasi," dalam Teosofi: Jurnal Tasawuf dan Pemikiran Islam, Vol. 5 No. 2 (2015), h. 431-454; Kunawi Basyir, "Menggugat Syirik Intelektual Bersama Nasr Hâmid Abû Zayd dan Amina Wadud," dalam Teosofi: Jurnal Tasawuf dan Pemikiran Islam, Vol. 1 No. 2 (2011), h. 317-334; Yayuk Fauziyah, "Ulama Perempuan dan Dekonstruksi Fiqih Patriarkis," dalam Islamica: Jurnal Studi Keislaman, Vol. 5 No. 1 (2010), h. 161-174; Rofhani, "Ekspresi dan Representasi Budaya Perempuan Muslim Kelas Menengah di Surabaya," dalam Islamica: Jurnal Studi Keislaman, Vol. 11 No. 2 (2017), h. 277-310; Aji Damanuri, "Muslim Diaspora dalam Isu Identitas, Gender, dan Terorisme," dalam Islamica: Jurnal Studi Keislaman, Vol. 6 No. 2 (2012), h. 232-251; Muhammad Nasir, "the Resistance of Ulama Dayah Aceh Tamiang Against Women's Rights in Compilation of Islamic Law (KHI)," dalam MIQOT: Jurnal Ilmu-ilmu Keislaman, Vol. 41, No. 1, 2017. 